\title{
Experimental approaches to study the nutritional value of food Ingredients for dogs and cats
}

\author{
David L. Harmon
}

Department of Animal \& Food Sciences University of Kentucky, Lexington, 40546 USA

\begin{abstract}
This review covers methods that have been applied to study the nutrient value or quality of specific ingredients fed to dogs, cats and comparable species (i.e. foxes, minks, rats, etc.). Typically, the nutritional value or utilization of a specific ingredient is measured by total tract digestibility and has been expanded through the measurement of total nutrient balance (i.e. nitrogen or energy). However, to better understand digestion it is necessary to obtain a more accurate measurement of nutrients entering and leaving the small intestine. Accurate measurement of small intestinal digestion is crucial in dogs and cats because nutrient digestion and absorption occurs primarily in the small intestine. Measuring small intestinal digestibility requires access to digesta leaving the small intestine and can be obtained by placing a cannula at the terminal ileum. This approach also necessitates the use of markers (e.g. chromic oxide) to monitor flow of digesta. Specifically, this approach has been used for the direct measurement of intestinal digestion of carbohydrates and amino acids. It also permits a separate measurement of large intestinal digestion which is particularly useful for the study of fiber fermentation. Passage of foods through the gastrointestinal tract is also an important component of utilization and these methods are reviewed.
\end{abstract}

Key Words: canine, digestion, feline, ileum, marker, nutrition

\section{Introduction}

Digestibility is the underlying basis of all food evaluation systems. By definition, it is the fraction of consumed food that disappears as it passes through the gastrointestinal tract. Because interpretation of results can be confounded by endogenous components (e.g. epithelial cells, microbial cells, mucins, etc.) coming from the gastrointestinal tract, it is often referred to as apparent digestibility, particularly for nitrogenous components. Digestibility serves as the measure of dietary quality and nutrient availability used to evaluate foods, and as a basis to estimate dietary needs and requirements. A comprehensive volume on the evaluation of feedstuffs through digestibility experiments is available (Schneider \& Flatt, 1975).

Because of the endogenous components and the microbial transformations occurring in the terminal small and large intestines, procedures have also been developed to better define digestibility by measuring small intestinal digestibility. These methods require invasive approaches (Walker et al., 1994) and have been used to define small intestinal digestibility of amino acids in several ingredients commonly used in canine foods (Yamka et al., 2005a; Yamka et al., 2006). Determining the utilization of a specific dietary ingredient requires additional experimental considerations and decisions (Fan \& Sauer, 1995; Fan \& Sauer, 2002).

It is the purpose of this review to describe procedures that have been used in dogs and cats to determine digestibility and evaluate nutrient utilization and dietary ingredients as well as methods to study the passage of foods. Methods that have been applied in companion animals will be the primary focus; however, examples developed in other species will also be reviewed.

\section{Digestibility}

General procedures for the conduct of digestibility measurements have been described (Anonymous, 2007). The American Association of Feed Control Officials (AAFCO) is the U.S. organization responsible for the regulation of all 
animal foods sold. They oversee labeling regulations and claims associated with the label.

To determine the metabolizable energy (ME) value of a food for dogs and cats AAFCO requires the following. The test food must be fed:

- At least 6 fully grown, healthy, individually housed animals at least one year of age.

- The animals shall be acclimated to the test food for at least 5 days.

- The food shall be fed once daily at a constant amount to maintain body weight or offered ad libitum.

- Dogs $132 \mathrm{kcal}$ ME $\left(\mathrm{kg}^{0.75}\right)$

- Cats $70 \mathrm{kcal}$ ME (kg)

- Feces and (or) urine shall be collected for at least 5 days.

- Estimation of ME

- ME $=$ [gross energy of food consumed gross energy of feces collected - ((grams protein consumed - grams protein in feces) $\mathrm{X}$ correction factor for energy lost in urine)]/amount of food consumed

While these procedures are generally well accepted by the petfood industry they are by no means the only procedures for accurately determining digestibility. Nott et al. (1994) compared various collection periods for determining digestibility in dogs and cats. Six dogs were switched to a new food and feces were collected over days 4-7, 8-14 and 15-21. There were no differences in collection period for digestibility of dry matter (DM), energy, protein, fat or nitrogen free extract (NFE) despite a minimum of only 3 days adaptation to the food. However, for the cats there were differences between collection periods for digestibility of protein. These authors followed this study with a second experiment where six foods were fed to six separate groups of six cats to compare fecal output during days 8-14 and 15-21 following food introduction. They reported differences in wet fecal output between collection periods for both wet and dry cat foods indicating longer adaption periods may be required for cats.

In addition to adaptation, other factors including exercise, breed type, age and food form (dry vs. canned) have also been studied to determine any potential effects on digestibility of foods in dogs. Exercise $(30 \mathrm{~km} / \mathrm{d}$ on a treadmill versus $30 \mathrm{~min} / \mathrm{d}$ walking on a leash) did not affect digestibility coefficients obtained in dogs (Ahlstrom et al., 2006). Breed, or more importantly size of dog has been extensively studied in regards to digestibility. Comparisons of Beagles and Great Danes indicated that digestibilities of crude protein, fiber and NFE were lower in the Great Danes (Zentek \& Meyer, 1995). This is in contrast to early work suggesting no effect of breed on digestibilities in dogs (James \& McCay, 1950). Comparisons of 10 dog breeds ranging from 4.2 (Yorkshire Terriers) to $52.5 \mathrm{~kg}$ (Irish Wolfhounds) yielded remarkably similar estimates of digestibility of organic matter (range 88.3 $89.3 \%$ ), protein (range $84.5-88.2 \%$ ), fat (range $93.2-95.1 \%$ ) and NFE (range $90.3-91.8 \%$ ) for a dry food. Values for a canned food tended to have slightly greater ranges in digestibility but values were still very similar between breeds (Meyer $e t$ al., 1999). Digestibilities of a dry extruded food were also compared in four breeds of dogs (3.6 $46 \mathrm{~kg}$ mature body weight) as they aged from 11 60 weeks of age (Weber et al., 2003). These authors reported varying intakes between breeds whether expressed per kg body weight or per $\mathrm{kg}^{0.75}$ making comparisons between breeds difficult to interpret. However, as they progressed from 11 to 60 weeks of age there was an overall tendency for increased digestibility of DM, protein, fat, and energy. Swanson et al. (2004) also reported higher digestibilities of organic matter and fat in mature dogs (11 years old) compared with 5-month old dogs but these differences were lost as the young dogs approached 1 year of age.

Aging effects on digestibility has been studied in dogs and cats. When young (4 years) versus old (13 years) dogs were compared (Taylor et al., 1995) there were no differences between the age groups in digestibility of protein, fat or energy. Cats, however, exhibited a marked decline in energy and fat digestibility with age (Harper, 1998). Cats also have been shown to have reduced digestibility early in life (Harper \& Turner, 2000). Digestibility was measured in cats from 9-11, 14$16,19-21,24-25$ and 30-32 weeks of age and it was determined that digestibility increased up to 19 weeks and plateaued thereafter.

In summary, when considering factors such as age and breed in the design of digestion studies, it appears that little difference exists for dogs from 
1 to 12 years of age. There appears to be some developmental changes prior to one year of age that may affect digestibility values. Breed appears to exert little influence on the digestibility values obtained, with the possible exception of the giant breeds. This is in contrast to cats where digestibility appears to plateau at approximately 1.5 years of age. Data suggests that in cats longer adaptation periods may be required, and fat digestibility may decline continuously with age. These factors may need to be considered when designing experiments.

\section{Digestibility assays and models}

Data to predict the behavior of individual food ingredients is needed for proper formulation. It is not possible to evaluate every ingredient source in animal studies, thus assays for comparing ingredients are widely used to estimate quality. This is particularly true in regards to amino acid bioavailability. Methods for evaluating amino acid bioavailability have been reviewed (Parsons, 2000) and will not be addressed. Models that have been directly compared with the dog and cat include the cecectomized rooster (Johnson et al., 1998b), the blue fox, the mink and the rat (Ahlstrom \& Skrede, 1998; Hendriks \& Emmens, 1998; Krogdahl et al., 2004). The cecectomized rooster assay was used to compare ileal amino acid digestibility values with those obtained in the dog (Johnson et al., 1998a). The rooster assay had very high correlations ( $r=0.87$ to 0.92 ) for individual amino acid digestibilities with values obtained in the dog indicating that it was a useful means of predicting nutrient availability in the dog. Comparing the blue fox, the mink and the rat to the dog indicated that the blue fox gave very similar mean digestibility values to those obtained in the dog. The rat had lower protein and higher carbohydrate digestion whereas the mink had much lower protein and carbohydrate digestion. Surprisingly, the mink gave higher correlation coefficients for most nutrients (Ahlstrom \& Skrede, 1998).

In vitro systems for determining digestibility have also been developed. These range from complex, multi-compartment, computer controlled systems (Minekus et al., 1995; Minekus et al., 1999) to enzyme-test tube assays (Tonglet et al.,
2001). Their application to pet foods has been limited; however, high correlations with in vivo digestion have been reported (Tonglet et al., 2001). One problem described when evaluating commercial pet foods is the narrow range of results obtained, thus making the development of an accurate prediction model difficult.

\section{Intestinal digestibility}

To better define nutrient digestibility, researchers have developed methods to access digesta at various points in the digestive tract and thereby assess nutrient availability at various points in the process. One such approach is the placement of a cannula at the terminal ileum. This is the point where host digestion and absorption have been completed. However, the high $\mathrm{pH}$, high short-chain fatty acid concentrations and large numbers of bacteria (Strickling et al., 2000) indicate that substantial fermentation is occurring in the terminal small intestine.

The most accurate approach to determine small intestinal digestion may require samples proximal to the ileum; however, implementation may impose greater experimental variability because of the difficulty in defining a repeatable cannula location. The terminal ileum is easily identifiable and provides a consistent location. It allows digesta to be sampled prior to exiting the small intestine. This provides the potential to more accurately define nutrient digestion and availability because it avoids the extensive large intestinal fermentation.

Hendriks and Sritharan (2002) determined nutrient digestion at various points of the digestive tract of euthanitized $\operatorname{dogs}$ and reported significantly greater digestibilities of DM and protein but lower digestibilities of lysine and methionine for samples collected from the feces as compared to the ileum. The differences observed in their study clearly demonstrate how site of sampling affects digestibility estimates, particularly for amino acids and nitrogen $(\mathrm{N})$. It has been estimated that approximately $50 \%$ of fecal $\mathrm{N}$ is of bacterial origin (Karr-Lilienthal et al., 2004) and thus the amount of $\mathrm{N}$ fluctuates depending on the fermentability of the food (Muir et al., 1996; Silvio et al., 2000). With foods containing highly fermentable fiber, fecal $\mathrm{N}$ digestibility can actually be lower than small

() 2007 Sociedade Brasileira de Zootecnia 
intestinal N digestibility (Muir et al., 1996; Silvio et al., 2000).

The surgical placement of intestinal cannulas for the study of digestive processes has a very long history with published reports in the 1930's (Harmon \& Richards, 1997). More recent methods have been published for swine (Hamilton C.R., 1985; Landers et al., 1989; Moughan P.J., 1987; Walker W.R., 1986). It is thought the first such procedures described to study intestinal digestion in the dog were by Brass (Brass \& Mundt, 1981; Brass \& Schunemann, 1989). They described surgical procedures and showed that total tract organic matter digestibility was similar in cannulated and intact dogs. As one might expect, using such a preparation for long term experiments in the dog poses some special problems. First and foremost is the nature and desire of the dog to chew. Cannula design and or materials must overcome the dog's ability to destroy many materials commonly used for cannulas. This concern may be overcome by choosing a metallic cannula; however, weight is a very critical issue as cannulas that are heavy will be extruded. In fact, extrusion is one of the most common reported complications (Brass \& Schunemann, 1989; Hill et al., 1996b). The other common reported complication is abscesses in the areas adjacent to the fistula (Brass \& Schunemann, 1989; Hill et al., 1996b). This problem has been described (Brass \& Schunemann, 1989) and occurs in the subcutaneous connective tissues around the barrel of the cannula as it exits through the body wall. It is thought to occur because of the high proteolytic activity of ileal digesta (Hill et al., 1996b) as well as the high bacterial content. Both of these authors (Brass \& Schunemann, 1989; Hill et al., 1996b) report losing over half of their preparations to cannula extrusion and abscess. An alternative procedure (Walker et al., 1994) described a cannula and placement procedures in dogs with no extrusion occurrences and minimal problems with abscesses. This involved the use of a light weight PVC cannula and cleansing procedures following sampling to minimize irritation from digesta. This has been the most extensively used procedure for cannulating dogs (Clapper et al., 2001; Murray et al., 1999; Pope et al., 2006; Zuo et al., 1996) and we have maintained dogs with these cannulas for several years.

\section{Markers}

A critical discussion of markers is beyond the scope of this review and several excellent reviews are available (Kotb \& Luckey, 1972; Marais, 2000; Owens \& Hanson, 1992). This review will only discuss markers as they pertain to the ileally cannulated dog and the measurement of intestinal digestibility.

In order to determine digestion in the small intestine, a marker (M) is needed to estimate digesta flow at the ileum $\left(\mathrm{D}_{\text {Flow }}\right)$ and the marker concentration is measured in ileal digesta samples.

\section{$D_{\text {Flow }}, \mathrm{g} / \mathrm{day}=\mathrm{M}, \mathrm{mg} / \mathrm{day} /$ Ileal $\mathrm{M}, \mathrm{mg} / \mathrm{g}$ digesta}

The flow of any corresponding nutrient can be calculated by measuring the nutrient concentration in ileal digesta. Thus, intestinal disappearance $\left(\mathrm{I}_{\mathrm{d}}\right)$ is simply the difference between nutrient intake and ileal flow.

\section{$I_{d}, g /$ day = Intake, g/day - Ileal Flow, g/day}

The same concepts can be applied to the large intestine by comparing ileal and fecal nutrient flows. The key to obtaining accurate data is the behavior of the marker chosen for the experiment. The ideal characteristics have been described (Kotb \& Luckey, 1972);

- Non-absorbable

- Must not affect or be affected by the gastrointestinal tract or its microbes.

- Must be physically associated with or intimately associated with the material it is to mark.

- Analysis must be specific, sensitive and not interfere with other analyses.

A good criterion is that the marker is $100 \%$ recoverable in feces. Undoubtedly the most common marker used in nutrition research, and in companion animals, is chromic oxide $\left(\mathrm{Cr}_{2} \mathrm{O}_{3}\right)$. Unfortunately, frequency of use does not equate to a strict adherence to the rules of ideal behavior. Successful use of $\mathrm{Cr}_{2} \mathrm{O}_{3}$ to determine total tract digestibility in dogs has been reported (Lloyd \& McCay, 1954) and the use of $\mathrm{Cr}_{2} \mathrm{O}_{3}$ in ileally cannulated dogs has been evaluated (Hill et al., 1996a) by feeding foods containing differing 
proportions of animal and vegetable protein and measuring ileal and fecal recovery of $\mathrm{Cr}_{2} \mathrm{O}_{3}$. They found that ileal recovery of $\mathrm{Cr}_{2} \mathrm{O}_{3}$ (based on a 15hour continuous post-feeding collection of effluent) ranged from $93-98 \%$ and that estimates of ileal DM digestibility did not differ on day 2,3 or 4 of collection. This compares to an average ileal marker recovery of $73 \%$ (Walker et al., 1994) reported for a 12-hour collection following a dose of Cr:EDTA with a test meal. The differences in these two results is not surprising since ileal Tcannulas do not occlude total flow of digesta like some other types of cannulas (Harmon \& Richards, 1997) and quantitative collection of digesta should not be expected, but rather a representative sample can hopefully be obtained. Fecal recoveries (Hill et al., 1996a) of $\mathrm{Cr}_{2} \mathrm{O}_{3}$ ranged from 82 - $92 \%$ based on a 5 day fecal collection. Data from 7 previous experiments where fecal recovery of $\mathrm{Cr}$ was evaluated (Harmon, unpublished) yielded a range from 62 to $127 \%$ with an overall mean of $96.2 \pm 4$ (Figure 1). A closer examination of the relationship between fecal $\mathrm{Cr}_{2} \mathrm{O}_{3}$ recovery and dry matter digestibility indicates a relationship does exist $(\mathrm{r}$ $=0.73, \mathrm{n}=29, \mathrm{P}<0.0001)$. It is important to note that these dry matter digestibility values were determined from total fecal collections. However, a relationship that suggests marker recovery decreases with decreased digestibility is interesting. A relationship could occur because of faster passage in foods with lower digestibility emphasizing the poor association of $\mathrm{Cr}_{2} \mathrm{O}_{3}$ with the food. Marker recovery is seldom reported but these values are in the range of others (Johnson et al., 1998a). More recent data (Carciofi et al., 2007) reported recoveries in dogs ranging from 95 to $107 \%$ depending on food and method of analysis. Most of these reported fecal recoveries are also similar to those reported for cattle (Utley et al., 1970). In this study, heifers were orally dosed with ${ }^{51} \mathrm{Cr}_{2} \mathrm{O}_{3}$ and they recovered an average of $87 \%$ in 216 hours post-dosing. They also reported finding no radioactivity in the blood or urine. These results point out that $\mathrm{Cr}_{2} \mathrm{O}_{3}$ probably does not meet the criterion of intimate association with the food but that it does stay in the gastrointestinal tract, perhaps for extended periods. The large differences between experiments suggest dietary components could affect the outcome.

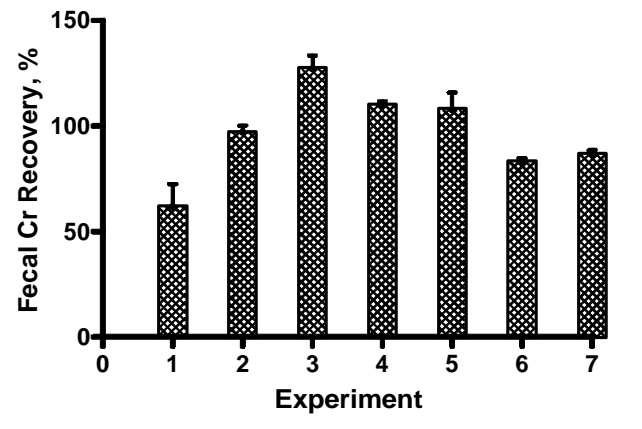

Figure 1 - Comparison of fecal Cr recovery.

Most studies using the ileally cannulated dog have used a multi-day sampling protocol (Cole et al., 1999; Yamka et al., 2003a) whereby ileal samples are collected 3-4 times per day on 3-4 separate days. The daily sampling hours are changed so that samples are collected on each hour of a 12-hour feeding cycle. These samples are then composited for the determination of ileal digestibility. It is believed that this type of sampling protocol will overcome some of the deficiencies from ideal behavior exhibited by $\mathrm{Cr}_{2} \mathrm{O}_{3}$ and result in a more representative sample of ileal digesta. In our studies, e.g. (Yamka et al., 2003a; Yamka et al., 2003b; Yamka et al., 2004; Yamka et al., 2005b; Yamka et al., 2005a) we also correct for fecal recovery of $\mathrm{Cr}_{2} \mathrm{O}_{3}$, i.e. $\mathrm{Cr}$ intake is equated to $\mathrm{Cr}$ excretion determined from multiple day fecal collections.

\section{Using digestibility to evaluate dietary ingredients}

A comprehensive treatise of methods used in the measurement of amino acid digestibility in pigs has been presented (Sauer et al., 2000). This serves as a valuable guide to measurements such as these in the dog and cat. Figure 2 depicts the relationships between various measurements used to assess amino acids. The aim is to assess the value of dietary amino acids as they supply the needs for tissue metabolism. Growth assays simultaneously encompass the principles of amino acid availability and utilization; however, most of what we do with companion animals occurs at maintenance rendering growth assays of limited value. This invokes a greater need for measures of digestibility to assess nutrient availability.

Limitations to total tract measures of $\mathrm{N}$

๑ 2007 Sociedade Brasileira de Zootecnia 
digestibility, particularly in relation to food fermentability have been discussed above.. Because increased fermentation increases microbial growth, it in turn increases fecal N, and thereby reduces apparent $\mathrm{N}$ digestibility (Figure 2). Another important factor in regards to measures such as these is endogenous N. When discussing intestinal digestibility versus total tract digestibility in the dog and cat it is apparent digestibility that is most often referred to. Whether digesta is collected at the terminal ileum or as feces there is a significant contribution of endogenous secretions. Sloughed cells, enzyme secretions, pancreatic secretions, and bile are all continuously produced, secreted, digested and reabsorbed. Estimates of endogenous ileal $\mathrm{N}$ flow for cats (Hendriks et al., 1996) ranged from 1.9 to $3.6 \mathrm{mg}$ $\mathrm{N} / \mathrm{g}$ dry food intake when measured by feeding a protein free versus an enzymatically hydrolyzed casein food, respectively. Numerous studies (Caine et al., 1997; de Lange et al., 1992; Fan et al., 1995; Lien et al., 1997b; Lien et al., 1997a) have been conducted to assess endogenous $\mathrm{N}$ contributions in swine, and these will not be dealt with here. However, it is important to understand the impact of endogenous contributions on the results obtained in companion animals.

Fan (1995) estimated the impact of endogenous amino acids on ileal amino acid digestibility. He found that across a wide range of dietary crude protein concentrations (4-24\%) ileal true amino acid digestibility was constant (Figure 3). However, apparent ileal amino acid digestibility increased as the protein content increased to a plateau near that for true digestibility. This occurs because endogenous contributions represent a greater contribution at low protein intakes. With the $12-24 \%$ protein foods, apparent ileal methionine digestibility ranged from approximately 88 to $92 \%$ while true methionine digestibility was approximately $94 \%$. The impact of factors such as these in the dog is less clear. When dietary crude protein content was varied from 10 to $25 \%$ by varying the proportion of lowash poultry meal (Yamka et al., 2003a), small intestinal amino acid digestibility was similar across all protein concentrations. Only isoleucine (increased) and tryptophan (decreased) had linear relationships with dietary crude protein content . When a similar experimental approach was used in the evaluation of corn gluten meal (Yamka et al., 2004), apparent small intestinal digestibility of histidine, isoleucine, leucine, phenylalanine and valine all increased linearly with increasing corn gluten meal (10 to $30 \%$ crude protein) in the food. Only leucine also had significant quadratic effects. These results are in contrast to results obtained in the evaluation of soybean meal (Yamka et al., 2003b). As dietary crude protein increased from 10 to $25 \%$ by increasing soybean meal the apparent small intestinal digestibility of all amino acids decreased linearly. These results are somewhat

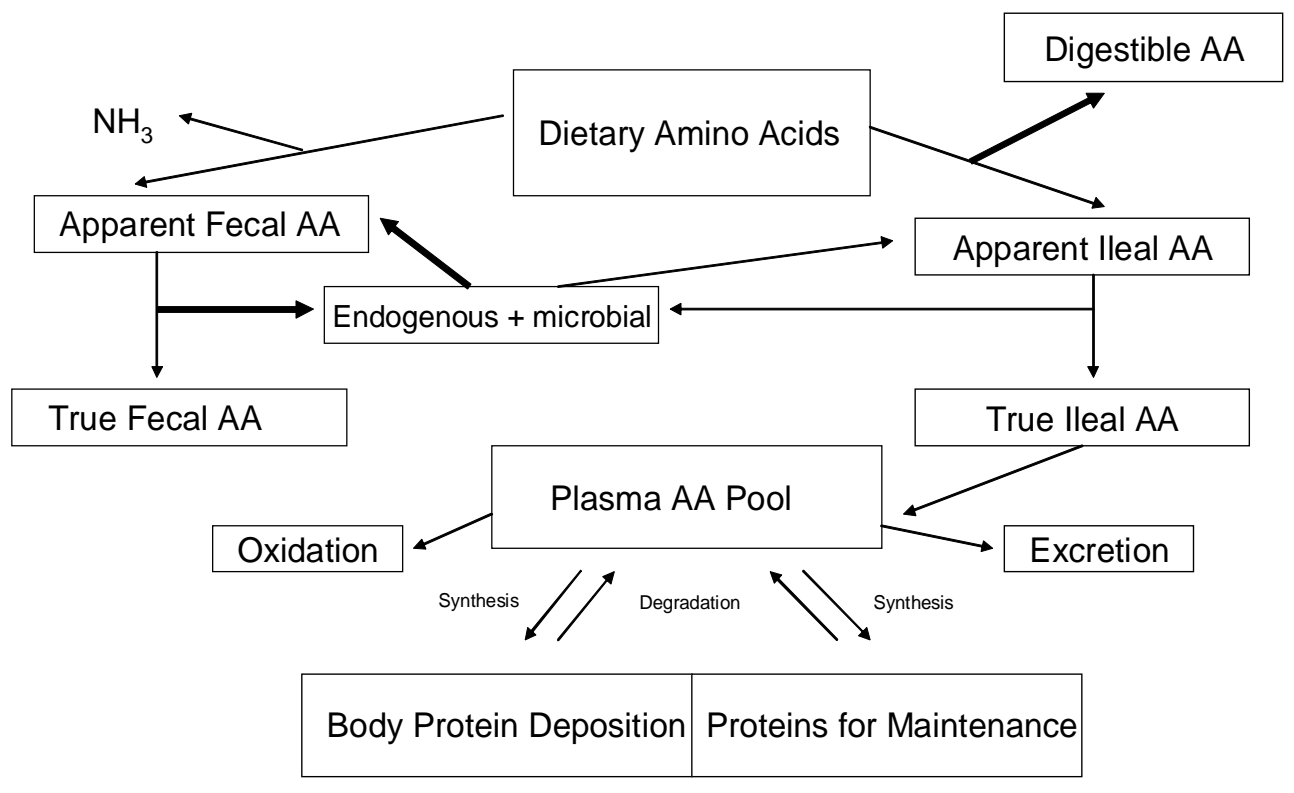

Figure 2 - Schematic of Amino Acid (AA) utilization adapted form Sauer et al. (2000).

() 2007 Sociedade Brasileira de Zootecnia 
unique and may be indicative of anti-nutritional components in the soybean meal used in this experiment. Generally, the dog exhibits consistently high small intestinal amino acid digestibilities. Over most common crude protein concentrations used endogenous amino acids have a minimal impact on the usefulness of the values obtained.

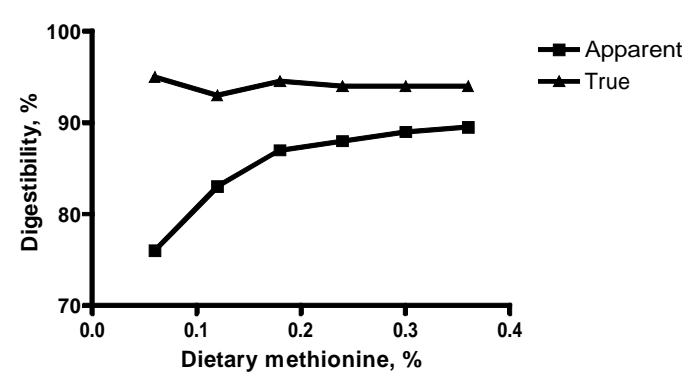

Figure 3 - Relationship between dietary methionine and digestibility. Fan et al. (1995).

\section{Methods for determining ingredient digestibility}

\section{Direct method}

The simplest approach for the evaluation of a dietary ingredient is the Direct Method (Sauer et al., 2000). In this approach, the ingredient to be evaluated is the sole supplier of the nutrient to be measured. Using this approach, the digestibility of any nutrient in this ingredient can be calculated as follows;

$$
D_{\text {apparent }}=\left(D_{\text {nutrient }} \times 100 \%\right) /\left(C_{\text {nutrient }} \times I_{\text {ingredient }}\right)
$$

$$
\begin{array}{ll}
\mathrm{D}_{\text {apparent }}= & \begin{array}{l}
\text { Apparent Digestibility of } \\
\text { Nutrient in Assay Ingredient, } \% \\
\text { Apparent Digestible Nutrient } \\
\mathrm{D}_{\text {nutrient }}= \\
\text { Content in Food, } \mathrm{g} / \mathrm{kg}
\end{array} \\
\mathrm{C}_{\text {nutrient }}=\quad \begin{array}{l}
\text { Nutrient Concentration in } \\
\text { Ingredient, } \mathrm{g} / \mathrm{kg}
\end{array} \\
\mathrm{I}_{\text {ingredient }}=\quad \begin{array}{l}
\text { Inclusion Level of Ingredient in } \\
\text { Food, } \%
\end{array}
\end{array}
$$

The Direct Method can be carried out with a single food; however, when considering feed grains, their low nutrient content, particularly for amino acids, it may give estimates that are influenced greatly by endogenous contributions.

\section{Difference Method}

This approach requires two experimental foods. A basal food based on a single ingredient similar to that used in the Direct Method where the ingredient to be evaluated is the sole supplier of the nutrient to be measured and a second food whereby the new ingredient to be evaluated is added to the basal food. Using this approach the apparent digestibility of a nutrient is equal to;

$$
\begin{aligned}
& D_{\text {apparent }}=D_{\text {basal }} \times I_{\text {basal }}+D_{\text {test }} \times I_{\text {test }} \\
& \mathrm{D}_{\text {apparent }}=\text { Apparent Digestibility of Nutrient } \\
& \text { in Assay Diet, \% } \\
& \mathrm{D}_{\text {basal }}=\text { Apparent Digestibility of Nutrient } \\
& \text { in Basal Ingredient, \% } \\
& \mathrm{I}_{\text {basal }}=\text { Inclusion Level of Basal Ingredient, } \\
& \mathrm{D}_{\text {test }}=\text { Apparent Digestibility of Nutrient } \\
& \text { in Test Ingredient, \% } \\
& I_{\text {test }}=\quad \text { Inclusion Level of Test Ingredient, \% }
\end{aligned}
$$

Using this approach the apparent digestibility in the basal ingredient $\left(\mathrm{D}_{\text {basal }}\right)$ is calculated using the direct method. The apparent digestibility of the test ingredient is then determined by difference;

$$
\mathbf{D}_{\text {test }}=\left(\mathbf{D}_{\text {apparent }}-\mathbf{D}_{\text {basal }} \times \mathbf{I}_{\text {basal }}\right) / \mathbf{I}_{\text {test }}
$$

When using the Difference Method one must assume there are no associative effects, i.e. the digestibility of the basal ingredient is the same when fed alone as when fed in combination with the new ingredient.

\section{Simultaneous equations}

A similar concept has been described (Schneider \& Flatt, 1975) whereby the basal and the new ingredients are fed in two foods, say 70:30 and 30:70. Apparent nutrient digestibility for each ingredient is then calculated by using simultaneous equations, e.g.

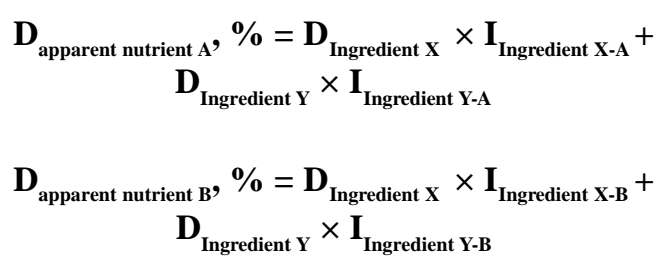

where;

() 2007 Sociedade Brasileira de Zootecnia 


\begin{tabular}{|c|c|}
\hline $\mathrm{D}_{\text {apparent nutrient A }}=$ & $\begin{array}{l}\text { Apparent Digestibility of } \\
\text { selected nutrient in Diet A }\end{array}$ \\
\hline $\mathrm{D}_{\text {apparent nutrient } \mathrm{B}}=$ & $\begin{array}{l}\text { Apparent Digestibility of } \\
\text { selected nutrient in Diet B }\end{array}$ \\
\hline $\mathrm{D}_{\text {Ingredient } \mathrm{X}}=$ & $\begin{array}{l}\text { Digestibility of selected } \\
\text { nutrient in } \operatorname{diet} \mathrm{A} \text { and } \mathrm{B}\end{array}$ \\
\hline $\mathrm{D}_{\text {Ingredient } \mathrm{Y}}=$ & $\begin{array}{l}\text { Digestibility of selected } \\
\text { nutrient in } \operatorname{diet} \mathrm{A} \text { and } \mathrm{B}\end{array}$ \\
\hline $\mathrm{I}_{\text {Ingredient X-A }}=$ & $\begin{array}{l}\text { Inclusion of Ingredient } X \\
\text { in Diet A }\end{array}$ \\
\hline $\mathrm{I}_{\text {Ingredient Y-A }}=$ & $\begin{array}{l}\text { Inclusion of Ingredient } \mathrm{Y} \\
\text { in Diet A }\end{array}$ \\
\hline $\mathrm{I}_{\text {Ingredient X-B }}=$ & $\begin{array}{l}\text { Inclusion of Ingredient } X \\
\text { in Diet B }\end{array}$ \\
\hline $\mathrm{I}_{\text {Ingredient Y-B }}=$ & $\begin{array}{l}\text { Inclusion of Ingredient } \mathrm{Y} \\
\text { in Diet } \mathrm{B}\end{array}$ \\
\hline
\end{tabular}

This approach may be better when there is a concern in regards to associative effects in that both foods have a combination of the same ingredients and you can target the combination over any desired range to minimize the influence of potential associative effects.

\section{Regression Method.}

This approach requires a basal and a new ingredient to be evaluated and these are the sole suppliers of the nutrient to be evaluated. In this regard, it differs only from the above methods in that multiple combinations are formulated and both ingredients can be evaluated simultaneously. The application of linear regression assumes there are no associative effects. Results from each food can be fit to a linear model for either ingredient such that;

$$
D_{\text {apparent }}=Y \text {-intercept }+D_{A} \times I_{A}
$$

where;

$$
\begin{aligned}
& \mathrm{D}_{\text {apparent }}=\text { Apparent Digestibility of Nutrient } \\
& \text { in Assay Diet, \% } \\
& \mathrm{D}_{\mathrm{A}}=\quad \text { Apparent Digestibility of Ingredient } \\
& \text { A (slope) } \\
& I_{A}=\quad \text { Inclusion rate of Ingredient } A \text { in } \\
& \text { Diets }
\end{aligned}
$$

The Y-intercept equates to the nutrient digestibility of the alternate ingredient as it is the value where the main ingredient content is zero. This approach provides added confidence in that potential associative effects can be evaluated by how the data fits the model. Significant deviations from linearity would not be acceptable. Also, evaluating ingredients in a number of foods greatly increases the experimental replication; however, it also increases the labor required.

The three experimental approaches have been compared in a single experiment (Fan \& Sauer, 1995). These authors found all three methods gave similar results when evaluating a supplemental protein source in pigs. However, when evaluating a feed stuff with a low protein content (barley) for amino acid digestibility, they did not recommend the Direct Method because of the significant contribution of endogenous amino acids.

\section{Passage}

The study of the movement of foods through the gastrointestinal system has received considerable attention. As one reviews these efforts, there are nearly as many approaches employed as there are papers. They range from monitoring the time from eating until defecation (Lewis et al., 1994) highly invasive approaches employing multiple intestinal cannulas (Reppas et al., 1991; Zhao et al., 1997) to indirect measures such as breath hydrogen (Papasouliotis et al., 1998). Generally speaking, there have been two aspects of passage estimated; 1) mean retention time or 2) gastric emptying rate. Mean retention time refers to the average time a substance spends in the gastrointestinal tract. This is usually estimated by feeding or dosing orally with a marker. Mean retention time is sometimes used interchangeably with transit time; however, transit time specifically refers to the time to transit the gastrointestinal tract. Estimation of transit time can be as simple as monitoring the time from consumption of a meal until defecation (Lewis et al., 1994).

\section{Mean Retention Time}

Generally, the measure of transit time is noninvasive in that measures can be made on materials collected with the feces. Mean retention time is most often determined using the following relationship:

$$
\begin{aligned}
& \text { Mean Retention Time }=\stackrel{n}{\Sigma} \mathbf{t}_{i} \mathbf{c}_{i} \Delta \mathbf{t}_{i} / \stackrel{\mathbf{n}}{\Sigma}_{\mathbf{i}} \Delta \mathbf{t}_{\mathrm{i}} \\
& \mathbf{i}=\mathbf{1} \quad \mathrm{i}=\mathbf{1}
\end{aligned}
$$


where $c_{i}$ is the concentration of marker in the $i_{\text {th }}$ sample, collected at time $t_{i}$ over a time interval $\Sigma t_{i}$ and $\mathrm{n}$ is the number of samples collected (Fahey, Jr. et al., 1990d). This approach assumes steady state conditions exist within the gastrointestinal tract, i.e. food intake and fecal excretion are constant. Obviously, this is never achieved in practice but it does point out how aspects such as behavior could influence results. Despite these concerns this method has been applied successfully (Fahey, Jr. et al., 1990d; Fahey, Jr. et al., 1990b; Fahey, Jr. et al., 1992) to determine the impact of dietary fiber addition on mean retention time. These experiments used $\mathrm{Cr}$ mordanted fiber (Uden et al., 1980) isolated from beet pulp as their marker. The fecal excretion of $\mathrm{Cr}$ was measured to estimate mean retention time.

A similar approach has been used in dogs; however, instead of $\mathrm{Cr}$ mordanted fiber they used plastic beads (Hernot et al., 2005). Dogs were dosed for 3 consecutive days with 20 plastic beads. Each days beads were a different color. The beads were then collected form the feces by sieving and counted. Polyethylene discs (3 $\mathrm{mm}$ diameter) have also been similarly used to estimate mean retention time in dogs (Cherbut \& Ruckebusch, 1985). Burrows et al. (1982) similarly determined mean transit time; however, they used radiopaque tubing cut into small pieces and mixed with the food. The feces was collected at timed intervals and radiographed to determine the quantity excreted.

To my knowledge, there have been no comparative studies to evaluate differences in marker behavior. Large differences exist in particles size, density of marker, and variations in sampling protocol exist between these reports. Estimates of mean retention time range from as short as 13 hours (Fahey, Jr. et al., 1990c) to as long as 33 hours (Fahey, Jr. et al., 1990a) using the same marker with different experimental foods. Breed, or more specifically, shoulder height, is highly correlated with mean retention time in dogs (Hernot et al., 2005). Their estimates for mean retention time ranged from 24 to 55 hours. This large range of retention times suggests that values may only be comparable within an experiment and animal differences need to be carefully considered in the design of the experiment.

\section{Gastric Emptying}

Several studies have specifically focused on gastric emptying or the time food spends in the stomach. An excellent and very thorough review of the processes regulating gastric emptying and the methods used to determine it experimentally is available (Wyse et al., 2003a). Many of these approaches have been developed and used clinically. This review will review the major methods that have been used in nutrition studies with dogs and cats.

The goal is to determine when a marker, or more importantly, a food exits the stomach. This requires the ability to quantify an internal marker, externally. There have been 3 major approaches 1) radioscintigraphy where gamma emissions from an administered radioisotope are quantified or 2) radiography whereby radio-opaque materials are quantified using radiographs and 3) stable isotopes where ${ }^{13} \mathrm{CO}_{2}$ is measured in expired breath.

Gastric emptying and intestinal transit were both monitored in dogs using ${ }^{131}$ I-cellulose (Malagelada et al., 1980). The authors showed that the labeled fiber was stable (based on no blood ${ }^{131} \mathrm{I}$ ) and that it could be quantified using gamma scintigraphy. One disadvantage is animals must be anesthetized to monitor passage; however, it is otherwise noninvasive. A similar approach has been applied to cats (Foster et al., 1999) fed a food labeled with ${ }^{99 \mathrm{~m}} \mathrm{Tc}$-disofenin. While quantitative data was reported it is unclear how well the marker associated with the individual foods as no differences were seen with high fat versus high protein foods.

Polyethylene impregnated with barium sulphate was used to monitor gastric emptying (Weber et al., 2001) in large breed dogs. Dogs were dosed with 30 of these beads $(1.5 \mathrm{~mm})$ mixed with the food. They were trained to radiographic procedures to allow the beads to be counted without anesthetizing the dogs.

Radiopaque markers and colored plastic beads all can provide useful indexes of gastric emptying and gastrointestinal transit. They offer the needed benefit of being largely noninvasive; however, they all suffer to some degree in their ability to mimic the test foods. The rate at which they leave the stomach and pass through the gastrointestinal tract varies with their size and density and since they are inert they do not mimic any of the digestive processes that occur with the food. One 
marker that may overcome some of these limitations is ${ }^{13} \mathrm{C}$-octanoic acid (Bourreau et al., 2004). Octanoic acid is a medium chain fatty acid that is rapidly absorbed from the duodenum after exiting the stomach. It then goes via the portal circulation to the liver where it is extensively oxidized. The test food is labeled with ${ }^{13} \mathrm{C}$-octanoic acid and ${ }^{13} \mathrm{CO}_{2}$ is monitored in expired air. Breath samples are collected at 15 minute intervals using a face mask and ${ }^{13} \mathrm{CO}_{2}$ is measured in the breath sample using isotope ratio mass spectrometry. Comparisons between scintigraphy and the ${ }^{13} \mathrm{CO}_{2}$ breath test in humans (Choi et al., 1997) did not yield similar estimates of gastric emptying. They reported that although the assay was very reproducible, the lag time associated with the absorption and oxidation of ${ }^{13} \mathrm{C}$-octanoic acid may limit its usefulness clinically. These observations were confirmed in the dog (Wyse et al., 2003b) by comparing the appearance of ${ }^{13} \mathrm{CO}_{2}$ in breath with ${ }^{2} \mathrm{H}_{2} \mathrm{O}$ in saliva following dosing with ${ }^{13} \mathrm{C}$ octanoic acid or ${ }^{2} \mathrm{H}$-octanoic acid. Comparisons of half-life $\left(\mathrm{t}_{1 / 2}\right)$ and time to maximum concentration were over 1 hour greater for ${ }^{13} \mathrm{C}$.

\section{Flatulence}

There has been very limited research reported on the incidence and severity of flatulence in dogs. Some believe flatulence is of little concern (Jones et al., 1998) while others have attempted to decrease flatulence by addition of inhibitors and binding compounds to the food (Giffard et al., 2001). Regardless of opinion on severity and relevance, research has certainly been limited because of the difficulty in monitoring and quantifying flatulence severity. However, a method has been developed (Collins et al., 2001) for in vivo assessment of flatulence in dogs. Throughout the experiment, dogs wore vests containing a monitoring pump which would sample air near the anus and measure hydrogen sulfide concentrations. Using this system, these authors were then able to determine flatulence frequency and hydrogen sulfide concentrations. This approach was used by Yamka et al. (2006) to compare high- and lowoligosaccharide soy-based foods with poultry byproduct meal based foods in dogs. Using this approach they reported no differences between foods for total episodes per day, daily $\mathrm{H}_{2} \mathrm{~S}(\mu \mathrm{g} /$ day), maximum $\mathrm{H}_{2} \mathrm{~S}(\mu \mathrm{g} / \mathrm{mL})$ or offensiveness $(\mu \mathrm{g} /$
$\mathrm{mL}$ per episode). Collins et al. (2001) reported that the data were highly variable with mean coefficients of variation between days and between dogs on each day were 75 and $103 \%$, respectively. This is not surprising in that flatulence tends to be episodic and animal dependent. Both items contribute greatly to experimental variation.

\section{Literature cited}

AHLSTROM, O.; SKREDE, A. Comparative nutrient digestibility in dogs, blue foxes, mink and rats. Journal of Nutrition, v.128, p.2676S-2677S, 1998.

AHLSTROM, O.; SKREDE, A.; VHILE, S.G. et al. Effect of exercise on nutrient digestibility in trained hunting dogs fed a fixed amount of food. Journal of Nutrition, v.136, p.2066S-2068S, 2006.

ANONYMOUS. 2007 Official Publication Association of American Feed Control Officials. 2007.

BOURREAU, J.; HERNOT, D.; BAILHACHE, E. et al. Gastric emptying rate is inversely related to body weight in dog breeds of different sizes. Journal of Nutrition, v.134, p.2039S2041S, 2004.

BRASS, W.; MUNDT, H.C. Zur anlage von dauerkanulen im colon beim hund. Z Versuchstierkd, v.23, p.128-133, 1981.

BRASS, W.; SCHUNEMANN, C. Permanent fistulas in the ileum and colon of the dog; implantation, maintenance, use and effect on the digestive process. Fortshr Tierphysiol Tierernahrg, v.19, p.7-13, 1989.

BURROWS, C.F.; KRONFELD, D.S.; BANTA, C.A. et al. Effects of fiber on digestibility and transit time in dogs. Journal of Nutrition, v.112, p.1726-1732, 1982.

CAINE, W.R.; TAMMINGA, S.; VERSTEGEN, M.W. et al. Endogenous recoveries and true ileal digestibilities of amino acids in newly weaned pigs fed diets with protease-treated soybean meal. Journal of Animal Science, v.75, p.29702979, 1997.

CARCIOFI, A.C.; VASCONCELLOS, R.S.; DE OLIVEIRA, L.D. et al. Chromic oxide as a digestibility marker for dogs A comparison of methods of analysis.Animal and Feed Science Technology, v. (In Press), 2007.

CHERBUT, C.; RUCKEBUSCH,Y. The effect of indigestible particles on digestive transit time and colonic motility in dogs and pigs. British Journal of Nutrition, v.53, p.549-557, 1985.

CHOI, M.G.; CAMILLERI, M.; BURTON, D.D. et al. [13C] octanoic acid breath test for gastric emptying of solids: accuracy, reproducibility, and comparison with scintigraphy. Gastroenterology, v.112, p.1155-1162, 1997.

CLAPPER, G.M.; GRIESHOP, C.M.; MERCHEN, N.R. et al. Ileal and total tract nutrient digestibilities and fecal characteristics of dogs as affected by soybean protein inclusion in dry, extruded diets. Journal of Animal Science, v.79, p.1523-1532, 2001.

COLE, J.T.; FAHEY JR., G.C.; MERCHEN, N.R. et al. Soybean hulls as a dietary fiber source for dogs. Journal of Animal Science, v.77, p.917-924, 1999.

COLLINS, S.B.; PEREZ-CAMARGO, G.; GETTINBY.G. et al. Development of a technique for the in vivo assessment of flatulence in dogs. American Journal of Veterinary Research, v.62, p.1014-1019, 2001.

DE LANGE, C.F.M.; SAUER, W.C.; SOUFFRANT, W.B. et al. $15 \mathrm{~N}$-Leucine and $15 \mathrm{~N}$-isoleucine isotope dilution techniques versus the $15 \mathrm{~N}$-isotope dilution technique for determining the recovery of endogenous protein and amino acids in digesta collected from the distal ileum in pigs. 
Journal of Animal Science, v. 70, p. 1848-1856, 1992

FAHEY Jr., G.C.; MERCHEN, N.R.; CORBIN, J.E. et al. Dietary fiber for dogs: III. Effects of beet pulp and oat fiber additions to dog diets on nutrient intake, digestibility, metabolizable energy, and digesta mean retention time. Journal of Animal Science, v.70, p.1169-1174, 1992.

FAHEY Jr,G.C., MERCHEN, N.R.; CORBIN, J.E. et al. Dietary fiber for dogs: II. Iso-total dietary fiber (TDF) additions of divergent fiber sources to dog diets and their effects on nutrient intake, digestibility, metabolizable energy and digesta mean retention time. Journal of Animal Science, v.68, p.4229-4235, $1990 \mathrm{~b}$.

FAHEY Jr., G.C.; MERCHEN, N.R.; CORBIN, J.E. et al. Dietary fiber for dogs: II. Iso-total dietary fiber (TDF) additions of divergent fiber sources to dog diets and their effects on nutrient intake, digestibility, metabolizable energy and digesta mean retention time. Journal of Animal Science, v. 68, p.4229-4235, 1990a.

FAHEY Jr., G.C.; MERCHEN, N.R.; CORBIN, J.E. et al. Dietary fiber for dogs: I. Effects of graded levels of dietary beet pulp on nutrient intake, digestibility, metabolizable energy and digesta mean retention time. Journal of Animal Science, v.68, p.4221-4228, 1990d.

FAHEY Jr., G.C.; MERCHEN, N.R.; CORBIN, J.E. et al. Dietary fiber for dogs: I. Effects of graded levels of dietary beet pulp on nutrient intake, digestibility, metabolizable energy and digesta mean retention time. Journal of Animal Science, v.68, p.4221-4228, 1990c.

FAN, M.Z.; SAUER,W.C. Determination of apparent ileal amino acid digestibility in barley and canola meal for pigs with the direct, difference, and regression methods. Journal of Animal Science, v.73, p.2364-2374, 1995.

FAN, M.Z.; SAUER,W.C. Determination of true ileal amino acid digestibility and the endogenous amino acid outputs associated with barley samples for growing-finishing pigs by the regression analysis technique. Journal of Animal Science, v.80, p.1593-1605, 2002.

FAN, M.Z.; SAUER,W.C.; MCBURNEY, M.I. Estimation by regression analysis of endogenous amino acid levels in digesta collected from the distal ileum of pigs. Journal of Animal Science, v.73, p.2319-2328, 1995.

FOSTER, L.A.; HOSKINSON, J.J.; GOOGGIN, J.M. et al. Gastric emptying of diets varying in macronutrient composition in cats. Supplement to Compendium on Contunuing Education for the Practising Veterinarian, v.21, p.61-1999.

GIFFARD, C.J.; COLLINS, S.B.; STOODLEY, N.C. et al. Administration of charcoal, Yucca schidigera, and zinc acetate to reduce malodorous flatulence in dogs. Journal American Veterinary Medical Association, v.218, p.892-896, 2001.

HAMILTON, C.R. Simultaneous cecostomy and ileal cannulation with a modified flexible T cannula in gilts. American Journal of Veterinary Research, v.46, p.942-944, 1985.

HARMON, D.L.; RICHARDS, C.J. Considerations for gastointestinal cannulations in ruminants. Journal of Animal Science, v.75, p.2248-2255, 1997.

HARPER, E.J. Changing perspectives on aging and energy requirements: aging and digestive function in humans, dogs and cats. Journal of Nutrition, v.128, p.2632S-2635S, 1998.

HARPER, E.J.; TURNER,C.L. Age-related changes in apparent digestibility in growing kittens. Reproduction, Nutrition and Development, v.40, p.249-260, 2000.

HENDRIKS, W.H.; EMMENS, M. Apparent ileal nitrogen and amino acid digestibility of a moist cat food. Journal of Nutrition, v.128, p.2801S-2802S, 1998.

HENDRIKS, W.H.; MOUGHAN, P.J.; TARTTELIN, M.F. Gut endogenous nitrogen and amino acid excretions in adult domestic cats fed a protein-free diet or an enzymatically hydrolyzed casein-based diet. Journal of Nutrition, v.126, p. $955-962,1996$.
HENDRIKS,W.H.; SRITHARAN, K. Apparent ileal and fecal digestibility of dietary protein is different in dogs. Journal of Nutrition, v.132, p.1692S-1694S, 2002.

HERNOT, D.C.; BIOURGE, V.C.; MARTIN, L.J. et al. Relationship between total transit time and faecal quality in adult dogs differing in body size.Journal of Animal Physiology and Animal Nutrition (Berlin), v.89, p.189-193, 2005.

HILL, R.C.; BURROWS, C.F.; ELLISON, G.W. et al. The use of chromic oxide as a marker for measuring small intestinal digestibility in cannulated dogs. Journal of Animal Science, v.74, p.1629-1634, 1996a.

HILL, R.C.; ELLISON, G.W.; BURROWS, C.F. et al. Ileal cannulation and associated complications in dogs. Laboratory Animal Science, v.46, p.77-80, 1996b.

JAMES,W.T.; MCCAY,C.M. A study of food intake, activity, and digestive efficiency in different type dogs. American Journal of Veterinary Research, v. 11, p. 412-413, 1950.

JOHNSON, M.L.; PARSONS, C.M.; FAHEY JR, G.C. et al. Effects of species raw material source, ash content, and processing temperature on amino acid digestibility of animal by-product meals by cecectomized roosters and ileally cannulated dogs. Journal of Animal Science, v.76, p.11121122, 1998a.

JOHNSON, M.L.; PARSONS,C.M.; FAHEY Jr., G.C. et al. Effects of species raw material source, ash content, and processing temperature on amino acid digestibility of animal by-product meals by cecectomized roosters and ileally cannulated dogs. Journal of Animal Science, v.76, p.11121122, 1998b.

JONES, B.R.; JONES, K.S.; TURNER, K. et al. Flatulence in pet dogs. New Zealand Veterinary Journal, v.46, p.191193, 1998.

KARR-LILIENTHAL, L.K.; GRIESHOP, C.M.; SPEARS, J.K et al. Estimation of the proportion of bacterial nitrogen in canine feces using diaminopimelic acid as an internal bacterial marker. Journal of Animal Science, v.82, p.1707-1712, 2004.

KOTB, A.R.; LUCKEY, T.D. Markers in nutrition. Nutrition Abstract Reviews, v.42, p.813-845, 1972.

KROGDAHL, A.; AHLSTROM, O.; SKREDE, A. Nutrient digestibility of commercial dog foods using mink as a model. Journal of Nutrition, v.134, p.2141S-2144S, 2004.

LANDERS, B.R.; DEVITT, P.G.; JAMIESON, G.G. A modified Thomas cannula for duodenal cannulation in pigs. Australian Veterian Journal, v.66, p.182-183, 1989.

LEWIS, L.D.; MAGERKURTH, J.H.; ROUDEBUSH, P. et al. Stool characteristics, gastrointestinal transit time and nutrient digestibility in dogs fed different fiber sources. Journal of Nutrition, v.124, p.2716S-2718S, 1994.

LIEN, K.A.; SAUER, W.C.; DUGAN, M.E.R. Evaluation of the $15 \mathrm{~N}$-isotope dilution technique for determining the recovery of endogesnous protein in ileal digesta of pigs: Effect of the pattern of blood sampling, precursor pools, and isotope dilution technique. Journal of Animal Science, v.75, p.159169, 1997a.

LIEN, K.A.; SAUER,W.C.; MOSENTHIN, R. et al. Evaluation of the $15 \mathrm{~N}$-isotope dilution technique for determining the recovery of endogenous protein in ileal digestion of pigs: Effect of dilution in the precursor pool for endogenous nitrogen secretion. Journal of Animal Science, v.75, p.148158, 1997b.

LLOYD, L.E.; MCCAY, C.M. The use of chromic oxide in digestibility and balance studies with dogs. Journal of Nutrition, v.53, p.613-622, 1954.

MALAGELADA, J.R.; CARTER, S.E.; BROWN, M.L. et al. Radiolabeled fiber: a physiologic marker for gastric emptying and intestinal transit of solids. Digestive Disease Science, v.25, p.81-87, 1980 .

MARAIS, J. P. Use of markers. In:D’Mello, J. P. F. (Ed.) Farm 
Animal Metabolism and Nutrition. CAB International, New York, 2000. p.255-277.

MEYER, H.; ZENTEK, J.; HABERNOLL, H. et al. Digestibility and compatibility of mixed diets and faecal consistency in different breeds of dog. Zentralbl Veterinarmed A, v.46, p. 155-165, 1999

MINEKUS, M.; MARTEAU, P.; HAVENAAR, R. et al. A multicompartmental dynamic computer-controlled model simulating the stomach and small intestine. ATLA Alternat Lab Animals, v.23, p.197-209, 1995.

MINEKUS, M.; SMEETS-PEETERS, M.; BERNALIER, A. et al. A computer-controlled system to simulate conditions of the large intestine with peristaltic mixing, water absorption and absorption of fermentation products. Applied Microbiology and Biotechnology, v.53, p.108-114, 1999.

MOUGHAN P.J. A note on the effect of cannulation of the terminal ileum of the growing pig on the apparent ileal digestibility of amino acids in ground barley. Animal Production, p.319-321, 1987.

MUIR, H.E.; MURRAY, S.M.; FAHEY Jr,G.C. et al. Nutrient digestion by ileal cannulated dogs as affected by dietary fibers with various fermentation characteristics. Journal of Animal Science, v.74, p.1641-1648, 1996.

MURRAY,S.M.; PATIL,A.R.; FAHEY Jr, G.C. et al. Apparent digestibility and glycaemic responses to an experimental induced viscosity dietary fibre incorporated into an enteral formula fed to dogs cannulated in the ileum. Food Chemistry and Toxicology, v.37, p.47-56, 1999.

NOTT, H.M.; RIGBY, S.I.; JOHNSON, J.V. et al. Design of digestibility trials for dogs and cats. Journal of Nutrition, v. 124, p.2582S-2583S, 1994.

OWENS, F.N.; HANSON, C.F. External and internal markers for appraising site and extent of digestion in ruminants. Journal of Dairy Science, v.75, p.2605-2617, 1992.

PAPASOULIOTIS, K.; SPARKES, A.H.; GRUFFYDDJONES,T.J. et al. Use of the breath hydrogen test to assess the effect of age on orocecal transit time and carbohydrate assimilation in cats. American Journal of Veterinary Research, v.59, p.1299-1302, 1998.

PARSONS,C.M. In vitro and in vivo assays for determining amino acid bioavailability. Compendium of Continuing Education for the Practicing Veterinarian, v.22, p.9-11, 2000.

POPE, L.L.; FLICKINGER, E.A.; KARR-LILIENTHAL, L.K. et al. Effects of lactoferrin supplementation on ileal and total tract nutrient digestibility, gastrointestinal microbial populations, and immune characteristics of ileal cannulated, healthy, adult dogs. Archives Animal Nutrition, v.60, p.1022, 2006.

REPPAS, C.; MEYER, J.H.; SIROIS, P.J. et al. Effect of hydroxypropylmethylcellulose on gastrointestinal transit and luminal viscosity in dogs. Gastroenterology, v.100, p.12171223, 1991.

SAUER, W.C.; FAN, M.Z.; MOSENTHIN, R. et al. Methods for measuring ileal amino acid digestibility in pigs. In:D'Mello, J. P. F. (Ed.) Farm Animal Metabolism and Nutrition. CAB International, New York, 2000, p.279-306.

SCHNEIDER, B.H.; FLATT, W.P. The evaluation of feeds through digestibility experiments. University of Georgia Press, Athens, 1975.

SILVIO, J.; HARMON, D.L.; GROSS, K.L. et al. Influence of fiber fermentability on nutrient digestion in the dog. Nutrition, v.16, p.289-295, 2000.

STRICKLING, J.A.; HARMON, D.L.; DAWSON, K.A. et al. Evaluation of oligosaccharide addition to dog diets: influences on nutrient digestion and microbial populations. Animal Feed Science and Technology, v.86, p.205-219, 2000.

SWANSON, K.S.; KUZMUK, K.N.; SCHOOK, L.B. et al. Diet affects nutrient digestibility, hematology, and serum chemistry of senior and weanling dogs. Journal of Animal Science, v. 82, p. 1713-1724, 2004.

\footnotetext{
๑ 2007 Sociedade Brasileira de Zootecnia
}

TAYLOR, E.J.; ADAMS, C.; NEVILLE, R. Some nutritional aspects of ageing in dogs and cats. Proceedings of the Nutrition Society, v.54, p.645-656, 1995.

TONGLET, C.; JEUSETTE, I.; ISTASSE, L. et al. Prediction of protein digestibility in dog food by a multi-enzymatic method: a useful technique to develop. Journal of Animal Physiology and Animal Nutrition (Berlin), v.85, p. 189-194, 2001.

UDEN, P.; COLUCCI, P.E.; VAN SOEST, P.J. Investigation of chromium, cerium and cobalt as markers in digesta. Rate of passage studies. J Sci Food Agric, v.31, p.625-632, 1980.

UTLEY, P.R.; BOLING, J.A.; BRADLEY, N.W. et al. Recovery of radioactive chromic oxide from the bovine gastrointestinal tract. Journal of Nutrition, v.100, p.1227-1231, 1970.

WALKER W.R. Ileal cannulation in baby pigs with a simple TCannula. Journal of Animal Science, v.62, p.407-411, 1986.

WALKER, J.A.; HARMON, D.L.; GROSS, K.L. et al. Evaluation of nutrient utilization in the canine using the ileal cannulation technique. Journal of Nutrition, v.124, p.2672S-2676S, 1994.

WEBER, M.; MARTIN, L.; BIOURGE, V. et al. Influence of age and body size on the digestibility of a dry expanded diet in dogs. Journal of Animal Physiology and Animal Nutrition (Berlin), v.87, p.21-31, 2003.

WEBER, M.; STAMBOUli, F.; MARTIN, L. et al. Gastrointestinal transit of solid radiopaque markers in large and giant breed growing dogs. Journal of Animal Physiology and Animal Nutrition (Berlin), v.85, p.242-250, 2001.

WYSE, C.A.; MCLELLAN, J.; DICKIE, A.M. et al. A review of methods for assessment of the rate of gastric emptying in the dog and cat: 1898-2002. Journal of Veterinary Internal Medicine, v.17, p.609-621, 2003a.

WYSE, C.A.; YAM, P.S.; SLATER, C. et al. A comparison of the rate of recovery of $13 \mathrm{CO}_{2}$ in exhaled breath with $2 \mathrm{H}$ in body water following ingestion of [2H/13C]octanoic acid in a dog. Research in Veterinary Science, v.74, p.123-127, 2003b.

YAMKA, R.M.; HARMON, D.L.; SCHOENHERR, W.D. et al. In vivo measurement of flatulence and nutrient digestibility in dogs fed poultry by-product meal, conventional soybean meal, and low-oligosaccharide low-phytate soybean meal. American Journal of Veterinary Research, v.67, p.88-94, 2006.

YAMKA, R.M.; HETZLER, B.M.; HARMON, D.L. Evaluation of low-oligosaccharide, low-phytate whole soybeans and soybean meal in canine foods. Journal of Animal Science, v. 83, p.393-399, 2005a.

YAMKA, R.M.; JAMIKORN, U.; TRUE, A.D. et al. Evaluation of low-ash poultry meal as a protein source in canine foods. Journal of Animal Science, v.81, p.2279-2284, 9-1-2003a.

YAMKA, R.M.; JAMIKORN, U.; TRUE, A.D. et al. Evaluation of soybean meal as a protein source in canine foods. Animal and Feed Science Technology, v.109, p.121-132, 2003b.

YAMKA, R.M.; KITTS, S.E.; HARMON, D.L. Evaluation of low-oligosaccharide low-phytate whole soya beans in canine foods. Animal and Feed Science Technology, v.120, p.7991, 2005b.

YAMKA, R.M.; KITTS, S.E.; TRUE, A.D. et al. Evaluation of maize gluten meal as a protein source in canine foods. Animal and Feed Science Technology, v.116, p.239-248, 2004.

ZENTEK, J.; MEYER, H. Normal handling of diets-are all dogs created equal? Journal of Small Animal Practice, v.36, p.354-359, 1995 ,

ZHAO, X.T.; MCCAMISH, M.A.; MILLER, R.H. et al. Intestinal transit and absorption of soy protein in dogs depend on load and degree of protein hydrolysis. Journal of Nutrition, v.127, p.2350-2356, 1997.

ZUO,Y .; FAHEY Jr, G.C.; MERCHEN, N.R. et al. Digestion responses to low oligosaccharide soybean meal by ileallycannulated dogs. Journal of Animal Science, v.74, p.24412449, 1996. 